Article

\title{
Structural Application of Eco-Friendly Composites from Recycled Wood Fibres Bonded with Magnesium Lignosulfonate
}

\author{
Petar Antov ${ }^{1, *(\mathbb{D})}$, Vassil Jivkov ${ }^{2}$, Viktor Savov ${ }^{1}$, Ralitsa Simeonova ${ }^{2}$ and Nikolay Yavorov ${ }^{3}$ \\ 1 Department of Mechanical Wood Technology, Faculty of Forest Industry, University of Forestry, 1797 Sofia, \\ Bulgaria; victor_savov@ltu.bg \\ 2 Department of Interior and Furniture Design, Faculty of Forest Industry, University of Forestry, 1797 Sofia, \\ Bulgaria; v_jivkov@ltu.bg (V.J.); r_simeonova@ltu.bg (R.S.) \\ 3 Department of Pulp, Paper and Printing Arts, University of Chemical Technology and Metallurgy, 1797 Sofia, \\ Bulgaria; yavorof@uctm.edu \\ * Correspondence: p.antov@ltu.bg
}

Received: 14 October 2020; Accepted: 24 October 2020; Published: 26 October 2020

check for updates

\begin{abstract}
The pulp and paper industry generates substantial amounts of solid waste and wastewater, which contain waste fibres. The potential of using these recycled wood fibres for producing eco-friendly composites that were bonded with a formaldehyde-free adhesive (magnesium lignosulfonate) and their use in structural applications was evaluated in this study. Fibreboards were produced in the laboratory with a density of $720 \mathrm{~kg} \cdot \mathrm{m}^{-3}$ and $15 \%$ magnesium lignosulfonate gluing content, based on the dry fibres. The mechanical properties (bending strength, modulus of elasticity and internal bond strength), physical properties (thickness swelling and water absorption) and formaldehyde content were determined and compared with the European Standards requirements for wood-based panels. In general, the laboratory-produced panels demonstrated acceptable mechanical properties, such as bending strength $\left(18.5 \mathrm{~N} \cdot \mathrm{mm}^{-2}\right)$ and modulus of elasticity $\left(2225 \mathrm{~N} \cdot \mathrm{mm}^{-2}\right)$, which were higher than the minimum requirements for type P2 particleboards and equal to the requirements for MDF panels. The moisture properties, i.e., thickness swelling $(24 \mathrm{~h})$ and water absorption $(24 \mathrm{~h})$ significantly deteriorated. The free formaldehyde content of the laboratory-produced composites $(1.1 \mathrm{mg} / 100 \mathrm{~g})$ reached the super E0 grade $(\leq 1.5 \mathrm{mg} / 100 \mathrm{~g})$, which allowed for their classification as eco-friendly, low-emission wood-based composites. The L-type corner joints, made from the developed composites, demonstrated significantly lower bending capacity (from 2.5 to 6.5 times) compared to the same joints made from MDF panels. Nevertheless, the new eco-friendly composites can be efficiently utilised as a structural material in non-load-bearing applications.
\end{abstract}

Keywords: wood composites; recycled fibres; bioadhesives; magnesium lignosulfonate; corner joints; bending strength capacity

\section{Introduction}

The depletion of fossil fuels and the increasing concern about the negative effects of global warming on the environment and human health are the main driving forces for the development of a bio-economy [1]. In this respect, the resource efficiency optimisation and the valorisation of lignocellulosic biomass in different high-value products from renewable sources as an alternative to their petroleum-based equivalents are one of the key objectives for implementing the circular economy principles in the wood-based panel industry [2-4]. Significant amounts of non-hazardous solid waste and sludge are generated annually at pulp and paper facilities worldwide, which require further 
utilisation [5-8]. This solid and liquid discharge contains residual fibres and represents a potential feedstock that can be utilised in the production of new panels [9-12].

Traditional thermosetting adhesives that are used for the production of wood-based composites, such as phenol-formaldehyde, urea-formaldehyde (UF), melamine-urea-formaldehyde and melamine-formaldehyde resins, are derived from the by-products of petroleum processing [13-15]. Currently, about $95 \%$ of the total wood adhesives that are used for manufacturing engineered wood composites are based on formaldehyde [16]. UF resins are the most predominant type, accounting for almost $85 \%$ of the total worldwide, followed by melamine at $10 \%$ and phenolics at $5 \%$ [16-18]. These adhesives have been extensively used in the production of wood-based panels because of their exceptional adhesion properties and water resistance, low curing temperatures, chemical versatility and cost-effectiveness $[13,15,19-24]$. The main disadvantage of these adhesives is the release of volatile organic compounds and formaldehyde from the finished engineered wood panels, especially in indoor applications $[25,26]$, causing adverse human health effects, such as skin and respiratory tract irritation, skin sensitisation, nausea, genotoxicity and sinonasal cancer [27-30]. Formaldehyde emission from engineered wood panels is dependent on endogenic factors, e.g., wood species, the adhesive used, the resin content, the technological conditions employed and the type of hot press $[13,16,31,32]$, and exogenic factors, which are related to the ambient conditions, processing and ageing of wood-based panels [32-35]. Thus, the growing social concern about hazardous formaldehyde emissions from engineered wood panels, along with the increased environmental consciousness related to the sustainability of the final products, have been the main factors for changing the industrial and scientific interest from the traditional petroleum-based synthetic resins to the development of renewable, bio-based and less toxic adhesives for manufacturing eco-friendly wood composites by partially or completely replacing formaldehyde in their compositions [36-48]. Different biomass sources, such as lignin $[37,49,50]$, soy proteins $[51,52]$, starch $[53,54]$ and tannins $[55,56]$, have been used as feedstocks for the development of biobased adhesives.

Lignin is a polyaromatic macromolecule and the second most abundant natural biopolymer in nature, preceded only by cellulose $[57,58]$. It is also generated as waste or a by-product of the pulp and paper industry, with an annual global production of approximately 50-75 million tons [59]. The main categories of lignin are lignosulfonates obtained from the sulfite pulping, kraft lignin from the sulfate process (Kraft pulping) and organosolv lignin from the production of bioethanol [60,61]. Currently, only $10 \%$ of technical lignin is further re-used at an industrial scale, while the rest is mainly burnt for energy, used to recover chemicals or disposed of as a waste [60,62]. Thus, the valorisation of lignin as an abundant and renewable component in the production of value-added products, including wood adhesives [13,42,63-65], could be an efficient way to achieve sustainable resource management. Lignin-based adhesives represent an eco-friendly alternative to the traditional petroleum-based resins as a promising strategy for integrating bio-refineries in the wood-based panel sector. Due to its phenolic hydroxyl groups, lignin is similar to phenol and may be used to partially replace phenol in the composition of phenol formaldehyde adhesives [66-69]. However, further research and chemical modification, such as methylolation and phenolation, is required to increase its lower reactivity to formaldehyde, especially in applications where a fast curing time is needed [37,42].

The production of lignosulfonates, which are the salts of lignin sulfonic acid, dominates the global technical lignin market, where the annual production is approximately $800,000-1.1$ million tons of solids $[70,71]$. They are obtained as by-products from the production of wood pulp by the sulphite lignin processing and are characterised by a very high molecular weight $(10,000-40,000 \mathrm{Da})$ and a high content of ash and sulfur of approximately $4.0-8.0 \%$ and $3.5-8.0 \%$, respectively [72]. The current industrial and scientific interest in incorporating lignosulfonates in adhesive formulations for the production of wood composites is due to their potential environmental and health advantages, i.e., the reduction of harmful formaldehyde emissions.

The aim of this study was to evaluate the potential of using novel eco-friendly fibreboards from recycled wood fibres that were bonded with magnesium lignosulfonate in structural applications, 
such as furniture, interior structures and claddings. For this purpose, the bending strength capacity of L-type corner joints, constructed from the developed composites using four different connection techniques for assembling, i.e., dowels, Confirmat, Minifix and screws, was determined.

\section{Materials and Methods}

The residual fibre mass, composed of the species Norway spruce (Picea abies Karst.) and Scots pine (Pinus silvestris L.) and oven-dried to $12 \%$ moisture content, was provided by the pulp and paper factory Mondi Stambolyiski EAD. The bulk density of the factory waste fibres was $44.86 \mathrm{~kg} \cdot \mathrm{m}^{-3}$. The waste fibres had lengths from 500 to $1000 \mu \mathrm{m}$ and $7 \%$ reduced lignin content.

Magnesium lignosulfonate at $15 \%$ gluing content (based on the dry weight of the fibres) was used as a binder. The lignosulfonate additive had the following characteristics: total solids content $-51.2 \%$, magnesium content $-6 \%$, reduced sugars $-7 \%$ and sulfate content $-2 \%$. European beech (Fagus sylvatica L.) veneers, made using the centric peeling process with an average thickness of $1.13 \mathrm{~mm}$ and a moisture content after drying and conditioning of approximately $7 \%$, were supplied by the factory Welde Bulgaria AD, and used for veneering the laboratory-produced fibreboards.

Under laboratory conditions, the fibreboards were produced with a $16 \mathrm{~mm}$ thickness and a $720 \mathrm{~kg} \cdot \mathrm{m}^{-3}$ target density. Residual fibres were mixed with the magnesium lignosulfonate in a high-speed laboratory adhesive mixer at $850 \mathrm{~min}^{-1}$. The hot pressing process was carried out using a single opening hydraulic press (PMC ST 100, Italy). The press temperature was $210^{\circ} \mathrm{C}$. The following four-stage pressing regime was used: in the first stage, the pressure applied was $4.5 \mathrm{MPa}$ for $1 \mathrm{~min}$; in the second stage, the pressure was steadily decreased to $2.23 \mathrm{MPa}$ for $3 \mathrm{~min}$; in the third stage, the pressure was decreased to $0.74 \mathrm{MPa}$ for $10 \mathrm{~min}$. The fourth pressing stage was performed at a pressure of $1.78 \mathrm{MPa}$ for $2 \mathrm{~min}$. The fabricated composites, after pressing, were conditioned for 10 days at $20 \pm 2{ }^{\circ} \mathrm{C}$ and $60-70 \%$ relative humidity.

The veneer sheets with dimensions of $400 \times 400 \mathrm{~mm}$ were cut. After that, the fibreboards were veneered using magnesium lignosulfonate at the content of $80 \mathrm{~g} \cdot \mathrm{m}^{-2}$ as an adhesive. A hand roller was used to apply the binder to the veneers in order to achieve a uniform adhesive layer. The veneering press factor used was $1 \mathrm{~min} \cdot \mathrm{mm}^{-1}$ of board thickness; the pressure applied was $0.6 \mathrm{MPa}$ at $200^{\circ} \mathrm{C}$.

The physical and mechanical properties of the fabricated panels (Figure 1) were tested according to the European Standards EN 310, EN 317, EN 322 and EN 323 [73-76]. A precision laboratory balance Kern (Kern \& Sohn GmbH, Balingen, Germany) with an accuracy of $0.01 \mathrm{~g}$ was used to determine the mass of the test specimens. The dimensions of the test pieces were measured using digital callipers with an accuracy of $0.01 \mathrm{~mm}$. The physical properties (water absorption and thickness swelling) were measured after $24 \mathrm{~h}$ of immersion in water. The thickness swelling was assessed using the differences between the initial and final panel thicknesses, and the water absorption was determined using the difference in weight. The mechanical properties of the panels were determined using a universal testing machine Zwick/Roell Z010 (Zwick/Roell GmbH, Ulm, Germany).

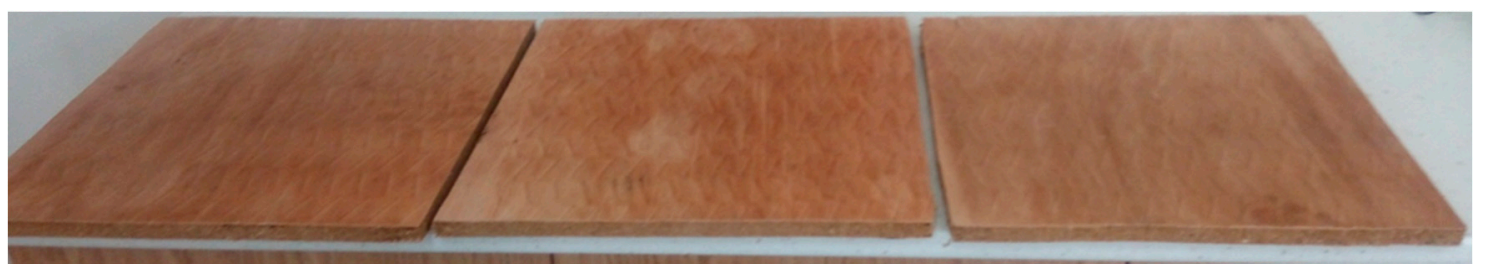

Figure 1. Eco-friendly panels from industrial waste fibres bonded with magnesium lignosulfonate and veneered with beech veneers; $720 \mathrm{~kg} \cdot \mathrm{m}^{-3}$ target density, $18 \mathrm{~mm}$ thickness and $15 \%$ lignosulfonate content.

The formaldehyde emission of the laboratory-produced panels was tested in the laboratory of Kronospan Bulgaria EOOD (Veliko Tarnovo, Bulgaria) on four test specimens in accordance with the standard perforator method [77]. 
For the evaluation of the bending strength of the joints made of the veneered eco-friendly composites from recycled wood fibres, L-shape test samples were prepared with the following dimensions: a length $L_{1}=L_{2}=106.4 \mathrm{~mm}$, a width $b=100 \mathrm{~mm}$ and a thickness $\delta_{1}=\delta_{2}=18 \mathrm{~mm}$, according to the test method [78] and as given in Figure 2.
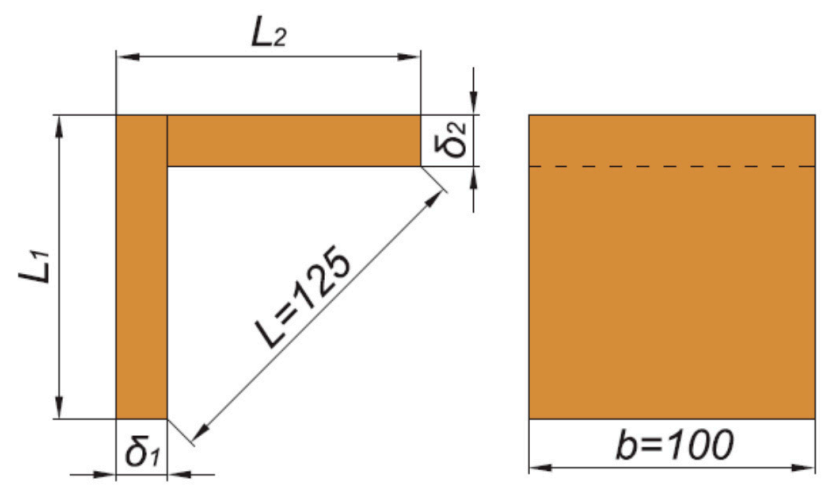

Figure 2. Type and dimensions of the tested samples [78].

Four types of end corner joints were selected, which are among the most used in furniture and interior constructions, where one was fixed with an adhesive and three with dismountable joints. Dowels with the dimensions $8 \times 30 \mathrm{~mm}$ and glued with polyvinyl acetate emulsion adhesive (PVA) represented the fixed joints. The following connectors were used in this study as dismountable joints: Minifix with connecting bolts made of steel B 34 for direct screwing (Figure 3a), Confirmat one-piece connector $7 \times 50 \mathrm{~mm}$ for screwing in holes $\varnothing 5 \mathrm{~mm}$ (Figure 3b) and mounting screws for wood $3.5 \times 50 \mathrm{~mm}$ (Figure 3c).

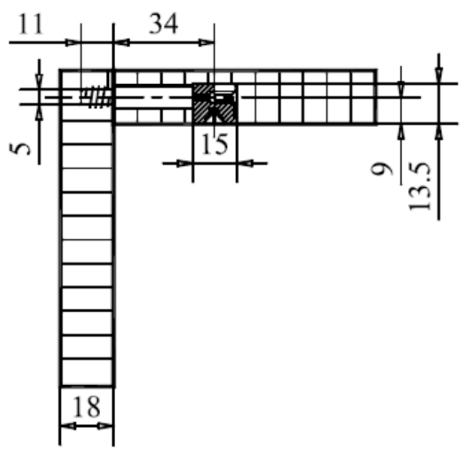

(a)

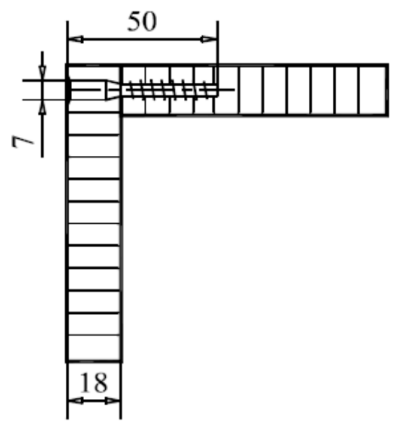

(b)

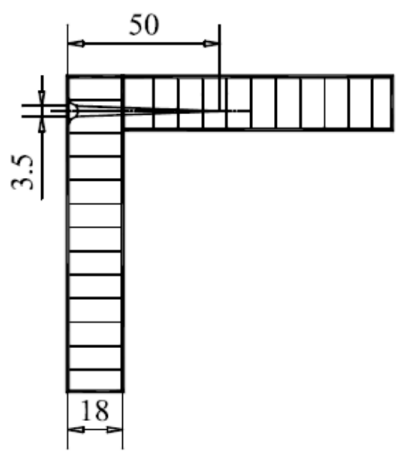

(c)

Figure 3. Types of joints: (a) Minifix, (b) one-piece connector Confirmat $\varnothing 7 \times 50 \mathrm{~mm}$ and (c) screw for wood $ø 3.5 \times 50 \mathrm{~mm}$. 
Seventeen test specimens were made using dowels, Minifix and Confirmat joints, and nine specimens were made with screw joints. All specimens were tested under compression bending loading according to the test scheme presented in Figure 4 [78].

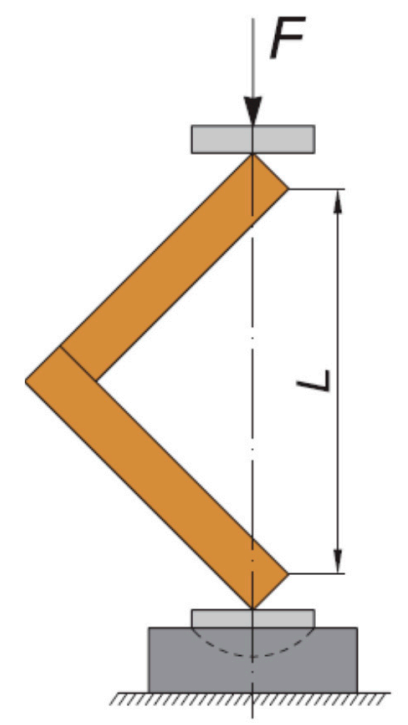

Figure 4. Type of loading of the tested samples [78].

The ultimate bending moment was determined according to the formula:

$$
M_{\max }=F_{\max } \cdot l,
$$

where:

$F_{\text {max }}$ is the maximum value of the loading force $(\mathrm{N})$.

$l$ is arm of bending $(\mathrm{m})$.

The results from a previous study [79] were used to compare the results obtained in the present one, where the same types of joints, made from beech veneered MDF panels with a thickness of $18 \mathrm{~mm}$ were tested under compression bending loading.

A statistical analysis of the results was done with XLSTAT (version 2020.2.3, Addinsoft Inc., New York, NY, USA). One-way ANOVA was performed on the results for the bending strength of the L-type corner joints for the analysis of variance at a 95\% confidence interval $(p<0.05)$. The statistical differences between the mean values were evaluated using the post hoc Tukey HSD (honestly significant difference) test.

\section{Results and Discussion}

\subsection{Formaldehyde Content}

The free formaldehyde content of the fabricated composites, tested in accordance with the standard EN ISO 12460-5, was determined to be $1.1 \pm 0.1 \mathrm{mg} / 100 \mathrm{~g}$, i.e., the super E0 emission grade $(\leq 1.5 \mathrm{mg} / 100 \mathrm{~g})$ was achieved. This value was remarkably low and can be considered as a zero formaldehyde content [13,77]. Taking into account the fact that natural wood releases low but still measurable amounts of formaldehyde [80], which is formed by its main components and extractives [81-83] at approximately 0.5 to $2 \mathrm{mg} / 100 \mathrm{~g}$ [13,37], our result allowed for defining the produced panels as eco-friendly composites. 


\subsection{Mechanical and Physical Properties}

The results for the mechanical and physical properties of the panels, which consisted of industrial waste fibres bonded with magnesium lignosulfonate, are presented in Table 1 . The density of the laboratory-produced panels varied from 681 to $772 \mathrm{~kg} \cdot \mathrm{m}^{-3}$, which was rather close to the targeted value. The difference in this main characteristic of the panels was significantly below $5 \%$; thus, it did not have an effect on the mechanical and physical properties.

Table 1. Mechanical and physical properties of the composites produced (MOR: modulus of rupture).

\begin{tabular}{|c|c|c|c|c|c|c|}
\hline Panel No. & $\begin{array}{c}\text { Density } \rho, \\
\left(\mathrm{kg} \cdot \mathrm{m}^{-3}\right)\end{array}$ & $\begin{array}{c}\text { Water } \\
\text { Absorption } \\
(24 \text { h) } A,(\%)\end{array}$ & $\begin{array}{l}\text { Thickness } \\
\text { Swelling ( } 24 \\
\text { h) } G t,(\%)\end{array}$ & $\begin{array}{l}\text { Bending } \\
\text { Strength } \\
(\mathrm{MOR}) \mathrm{fm} \text {, } \\
\left(\mathrm{N} \cdot \mathrm{mm}^{-2}\right)\end{array}$ & $\begin{array}{l}\text { Modulus of } \\
\text { Elasticity } \\
(\mathrm{MOE}) \mathrm{Em} \text {, } \\
\left(\mathrm{N} \cdot \mathrm{mm}^{-2}\right)\end{array}$ & $\begin{array}{l}\text { Internal } \\
\text { Bond } \\
\text { Strength } f t \text {, } \\
\left(\mathbf{N} \cdot \mathrm{mm}^{-2}\right)\end{array}$ \\
\hline 1 & $772 \pm 8.72$ & $150.97 \pm 4.87$ & $76.74 \pm 2.81$ & $17.0 \pm 0.67$ & $1990 \pm 53$ & $0.14 \pm 0.03$ \\
\hline 2 & $736 \pm 9.71$ & $175.52 \pm 4.25$ & $78.24 \pm 2.35$ & $18.9 \pm 0.76$ & $2260 \pm 61$ & $0.12 \pm 0.01$ \\
\hline 3 & $681 \pm 6.78$ & $184.36 \pm 5.73$ & $83.63 \pm 2.76$ & $20.6 \pm 1.32$ & $2450 \pm 72$ & $0.14 \pm 0.02$ \\
\hline 4 & $757 \pm 10.12$ & $144.65 \pm 5.91$ & $83.63 \pm 2.95$ & $17.0 \pm 1.49$ & $1930 \pm 49$ & $0.14 \pm 0.02$ \\
\hline 5 & $743 \pm 9.36$ & $180.06 \pm 4.74$ & $89.08 \pm 3.03$ & $20.6 \pm 0.93$ & $2280 \pm 67$ & $0.12 \pm 0.01$ \\
\hline 6 & $751 \pm 6.92$ & $163.36 \pm 6.01$ & $94.08 \pm 3.12$ & $16.6 \pm 1.37$ & $2180 \pm 56$ & $0.14 \pm 0.02$ \\
\hline 7 & $737 \pm 8.53$ & $178.99 \pm 5.38$ & $75.58 \pm 2.24$ & $17.8 \pm 1.52$ & $2320 \pm 42$ & $0.15 \pm 0.03$ \\
\hline
\end{tabular}

This study followed our previous research work [44], in which the mechanical and physical properties of the fabricated panels, produced from waste fibres and magnesium lignosulfonate as a binder, were investigated in more detail and compared with the European Standard requirements for common engineered wood panels [84,85]. Generally, the laboratory-produced panels demonstrated acceptable mechanical properties in terms of the bending strength (MOR) $\left(18.5 \mathrm{~N} \cdot \mathrm{mm}^{-2}\right)$ and modulus of elasticity (MOE) $\left(2225 \mathrm{~N} \cdot \mathrm{mm}^{-2}\right)$, which were greater than the lowest requirements for type P2 particleboards and equal to the minimum requirements for MDF panels. The deteriorated dimensional stability, i.e., water absorption $(24 \mathrm{~h})$ and thickness swelling $(24 \mathrm{~h})$, was the main drawback of the fabricated composites.

\subsection{Bending Strength of the L-type Corner Joints Made of the Fabricated Eco-friendly Composites}

The results of the bending strength are given in Table 2 and the boxplot graphic in Figure 5. The performance of the joints made of the eco-friendly composites with a Minifix connector was unsatisfactory. In practice, they cannot be used as connecting elements due to the fact that the bolt of Minifix reacts with a limited part of the panel and the pullout strength of this part of the connector is significantly less. The rest of the tested joints showed sufficient bending capacity. The highest bending capacity was demonstrated by the joints with $8 \times 30 \mathrm{~mm}$ dowels $(8.02 \mathrm{~N} \cdot \mathrm{m})$, followed by the Confirmat $\varnothing 7 \times 50 \mathrm{~mm}(6.95 \mathrm{~N} \cdot \mathrm{m})$ and screws for wood $\varnothing 3.5 \times 50 \mathrm{~mm}(4.94 \mathrm{~N} \cdot \mathrm{m})$. According to Tukey's test, a significant difference was observed only between the screw joints and the group of dowels and the Confirmat joints. The low strength of the joint with wood screws was due to the inhomogeneity of the eco-friendly panels fabricated from residual wood fibres. In contrast, the corner joints made from MDF panels exhibited an almost equal strength to the joints with the Confirmat and screws due to the homogeneity of the panels. This is proof that the small diameter of the screws had an adverse effect on the strength of the joint. Dowel joints constructed from eco-friendly composites showed almost 2.5 times lower bending capacity compared with the same joints made from MDF panels, while the joints with the Confirmat had a difference of 5 times and the joint with screws had a difference of 6.5 times. 
Table 2. Descriptive statistics for the bending strength capacity of L-type corner joints constructed from eco-friendly composites (Eco) and MDF.

\begin{tabular}{|c|c|c|c|c|c|c|c|c|}
\hline Statistic & $\begin{array}{l}\text { Dowels } \\
\text { Eco }\end{array}$ & $\begin{array}{c}\text { Confirmat } \\
\text { Eco }\end{array}$ & $\begin{array}{l}\text { Screw } \\
\text { Eco }\end{array}$ & $\begin{array}{l}\text { Minifix } \\
\text { MDF }\end{array}$ & $\begin{array}{l}\text { Rafix } \\
\text { MDF }\end{array}$ & $\begin{array}{l}\text { Dowels } \\
\text { MDF }\end{array}$ & $\begin{array}{l}\text { Screw } \\
\text { MDF }\end{array}$ & $\begin{array}{c}\text { Confirmat } \\
\text { MDF }\end{array}$ \\
\hline $\begin{array}{c}\text { No. of } \\
\text { observations }\end{array}$ & 17 & 17 & 9 & 15 & 15 & 15 & 15 & 17 \\
\hline Mean $(\mathrm{N} \cdot \mathrm{m})$ & 8.02 & 6.95 & 4.94 & 9.75 & 6.02 & 19.58 & 32.06 & 33.42 \\
\hline Minimum $(\mathrm{N} \cdot \mathrm{m})$ & 5.45 & 4.31 & 4.12 & 8.13 & 5.00 & 17.19 & 24.06 & 27.19 \\
\hline Maximum $(\mathrm{N} \cdot \mathrm{m})$ & 10.40 & 11.32 & 6.52 & 11.25 & 6.88 & 21.56 & 39.38 & 39.37 \\
\hline Median $(\mathrm{N} \cdot \mathrm{m})$ & 8.01 & 6.49 & 4.56 & 9.38 & 6.25 & 19.69 & 30.94 & 33.75 \\
\hline Variance $(\mathrm{N} \cdot \mathrm{m})$ & 2.07 & 4.47 & 0.61 & 1.11 & 0.44 & 1.53 & 19.97 & 11.99 \\
\hline St. Dev. $(\mathrm{N} \cdot \mathrm{m})$ & 1.44 & 2.12 & 0.78 & 1.05 & 0.66 & 1.24 & 4.47 & 3.46 \\
\hline Covariance & 0.18 & 0.30 & 0.16 & 0.11 & 0.11 & 0.06 & 0.14 & 0.10 \\
\hline
\end{tabular}

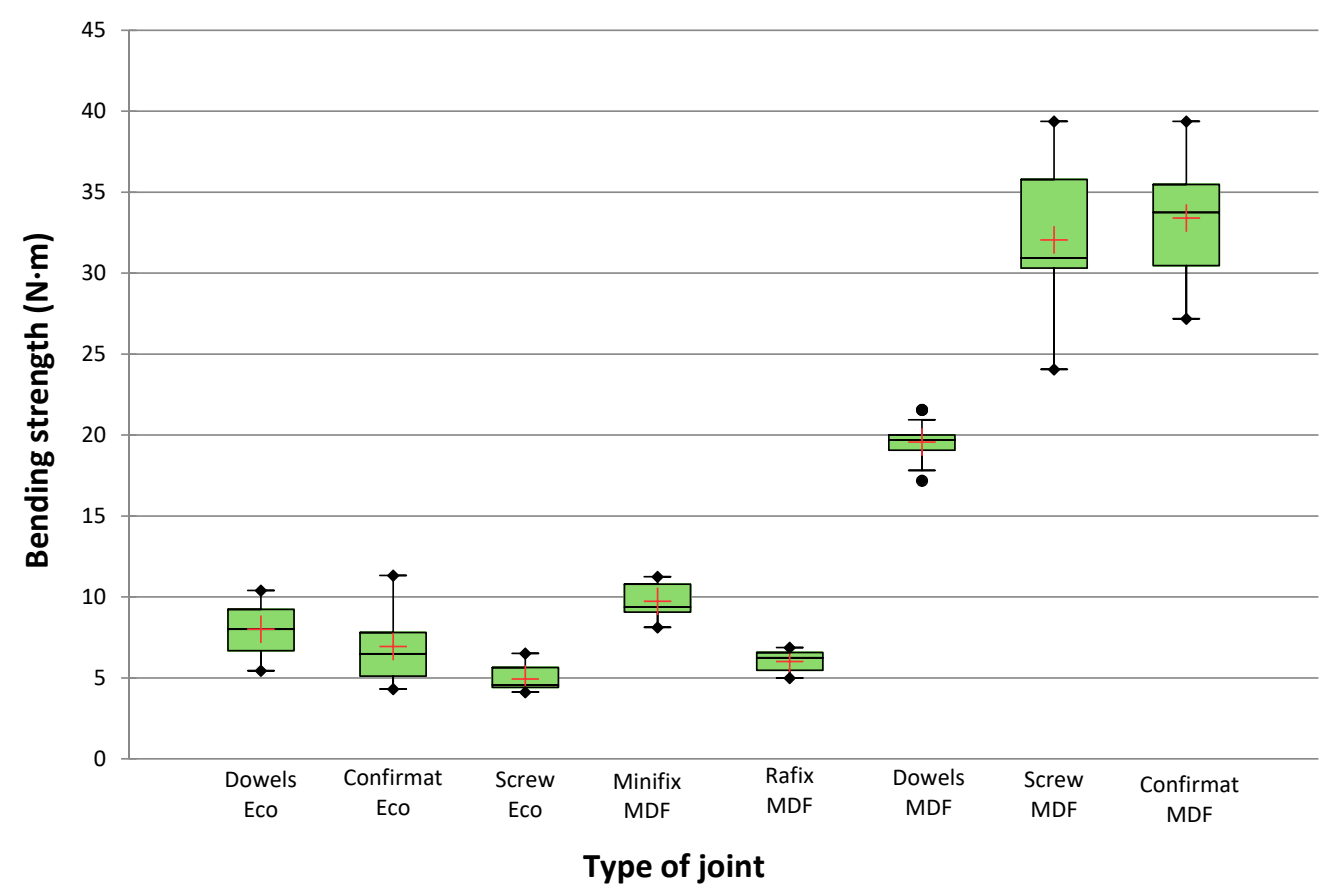

Figure 5. Bending strength under the compression test of L-type corner joints, which were constructed from eco-friendly composites and MDF.

From the statistical analysis of the one-way ANOVA test and the pairwise comparison performed with the Tukey HSD test, a significant difference of $\alpha=0.05$ at a confidence level of $95 \%$ was found in four groups between the obtained bending strength of the L-type end corner joints constructed from eco-friendly composites and MDF panels. The groups are presented in Table 3. All joints made of the eco-friendly composites fell in group " $\mathrm{D}$," together with Rafix in MDF. The dowel joints in the eco-friendly composites were in one group with Minifix in MDF. 
Table 3. Tukey honestly significant difference (HSD) analysis of the differences between the groups with a confidence interval of $95 \%$ of the bending capacity of joints of two materials of all pairwise comparisons.

\begin{tabular}{ccccc}
\hline \multirow{2}{*}{ Type of Joint } & \multicolumn{3}{c}{ Groups of Homogeneities $(\alpha=0.05)$} \\
& A & B & C & D \\
\hline Confirmat MDF & 33.417 & & & \\
Screw MDF & 32.063 & & & \\
Dowels MDF & & 19.583 & & \\
Minifix MDF & & & 9.750 & \\
Dowels Eco & & & 8.016 & 8.016 \\
Confirmat Eco & & & 6.951 \\
Rafix MDF & & & 6.021 \\
Screw Eco & & & 4.939 \\
\hline
\end{tabular}

\section{Conclusions}

Eco-friendly fibreboards with satisfactory mechanical and physical properties according to EN standards were produced from recycled fibres from the pulp and paper industry and bonded with magnesium lignosulfonate at $15 \%$ gluing content. The MOR and MOE values of the laboratory-produced composites were quite acceptable in comparison with the standard requirements for type P2 particleboards and almost equal to the minimum requirements for MDF panels [84,85].

The produced composites demonstrated a remarkably low formaldehyde content. The emission values, measured in accordance with the standard perforator method, were $\approx 1.1 \mathrm{mg} / 100 \mathrm{~g}$, i.e., the composites reached the super E0 emission class, which allowed for their classification as eco-friendly, low-emission composites [77].

The main disadvantage of the laboratory-produced composites was their deteriorated dimensional stability, i.e., water absorption and thickness swelling ( $24 \mathrm{~h})$. Hence, future investigations should focus on optimising the technological parameters and improving the lignosulfonate formula by adding suitable crosslinkers or catalysts.

The eco-friendly composites produced in this work can be used as a structural material with a limited application only, i.e., when applying minimal loads to the construction or as decorative panels. The Minifix connector was not suitable for joining the eco-friendly laboratory-produced composites. The tested L-type corner joints made of the fabricated eco-friendly composites demonstrated 2.5 to 6.5 times lower bending capacity compared to the same type of joints made of MDF panels with the same connectors. A higher bending capacity of the joints was achieved by improving the homogeneity of the composites and edgebanding of the structural elements.

Author Contributions: Conceptualisation, P.A., V.J. and V.S.; methodology, P.A., V.J. and V.S.; validation, P.A. and V.J.; investigation, V.J., V.S., R.S. and N.Y.; resources, P.A. and V.S.; writing the original draft preparation, P.A. and V.J.; writing-review and editing, P.A. and V.J.; visualisation, P.A., V.J. and V.S.; supervision, P.A. and V.J.; project administration, P.A. All authors have read and agreed to the published version of the manuscript.

Funding: This research was funded by project no. НИС-Б-1002/03.2019 “Exploitation Properties and Possibilities for Utilisation of Eco-friendly Bio-composite Materials", which was carried out at the facilities of the University of Forestry (Sofia, Bulgaria), in cooperation with the University of Chemical Technology and Metallurgy (Sofia, Bulgaria).

Conflicts of Interest: The authors declare no conflict of interest.

\section{References}

1. Arias, A.; González-García, S.; González-Rodríguez, S.; Feijoo, G.; Moreira, M.T. Cradle-to-gate Life Cycle Assessment of bio-adhesives for the wood panel industry. A comparison with petrochemical alternatives. Sci. Total Environ. 2020, 738, 140357. [CrossRef] [PubMed]

2. Vis, M.; Mantau, U.; Allen, B. (Eds.) Study on the Optimised Cascading Use of Wood, No 394/PP/ENT/RCH/14/7689, Final Report; Publications Office: Brussels, Belgium, 2016; p. 337. 
3. Nitzsche, R.; Budzinski, M.; Gröngröft, A. Techno-economic assessment of a woodbased biorefinery concept for the production of polymer-grade ethylene, organosolv lignin and fuel. Bioresour. Technol. 2016, 200, 928-939. [CrossRef] [PubMed]

4. Radoykova, T.; Nenkova, S.; Valchev, I. Balck liquor lignin products, isolation and characterization. J. Chem. Technol. Metall. 2013, 48, 524-529.

5. Bajpai, P. Generation of Waste in Pulp and Paper Mills. In Management of Pulp and Paper Mill Waste; Springer: Berlin/Heidelberg, Germany, 2015; ISBN 978-3-319-11788-1.

6. Krigstin, S.; Sain, M. Characterization and potential utilization of recycled paper mill sludge. Pulp. Paper Can. 2006, 107, 29-32.

7. Abubakr, S.; Smith, A.; Scott, G. Sludge characteristics and disposal alternatives for the pulp and paper industry. Madison. In Proceedings of the 1995 International Environmental Conference, Atlanta, GA, USA, 7-10 May 1995; pp. 269-279.

8. Ochoa de Alda, J.A.G. Feasibility of recycling pulp and pulp and paper sludge in the paper and board industries. Resour. Conserv. Recycl. 2008, 52, 965-972. [CrossRef]

9. Antov, P.; Savov, V. Possibilities for manufacturing eco-friendly medium density fibreboards from recycled fibres-A review. In Proceedings of the 30th International Conference on Wood Science and Technology-ICWST 2019 "Implementation of Wood Science in Woodworking Sector" and 70th Anniversary of Drvna Industrija Journal, Zagreb, Croatia, 12-13 December 2019; ISBN 978-953-292-062-8.

10. Davis, E.; Shaler, S.M.; Goodell, B. The incorporation of paper deinking sludge into fibreboard. For. Prod. J. 2003, 53, 46-54.

11. Geng, X.; Deng, J.; Zhang, S.Y. Characteristics of pulp and paper sludge and its utilization for the manufacture of medium density fibreboard. Wood Fiber. Sci. 2007, 39, 345-351.

12. Migneault, S.; Koubaa, A.; Nadji, H.; Riedl, B.; Zhang, S.Y.; Deng, J. Medium-density fibreboard produced using pulp and paper sludge from different pulping processes. Wood Fiber. Sci. 2010, 42, 292-303.

13. Mantanis, G.I.; Athanassiadou, E.T.; Barbu, M.C.; Wijnendaele, K. Adhesive systems used in the European particleboard, MDF and OSB industries. Wood Mater. Sci. Eng. 2018, 13, 104-116. [CrossRef]

14. Youngquist, J.A. Wood-based composites and panel products. In Wood Handbook: Wood as an Engineering Material; USDA Forest Service, Forest Products Laboratory: Madison, WI, USA, 1999; pp. 1-31.

15. Frihart, C.R. Wood adhesion and adhesives. In Handbook of Wood Chemistry and Wood Composites; Rowell, R.M., Ed.; CRC Press: Boca Raton, FL, USA, 2005; pp. 214-278.

16. Kumar, R.N.; Pizzi, A. Environmental Aspects of Adhesives-Emission of Formaldehyde. In Adhesives for Wood and Lignocellulosic Materials; Wiley-Scrivener Publishing: Hoboken, NJ, USA, 2019; pp. 293-312.

17. Byung-Dae, P.; Jae-Woo, K. Dynamic mechanical analysis of urea-formaldehyde resin adhesives with different formaldehyde-to-urea molar ratios. J. Appl. Polym. Sci. 2008, 108, 2045-2051.

18. Costa, N.; Pereira, J.; Ferra, J.; Cruz, P.; Martins, J.; Magalhāes, F.; Mendes, A.; Carvalho, L.H. Scavengers for achieving zero formaldehyde emission of wood-based panels. Wood Sci. Technol. 2013, 47, 1261-1272. [CrossRef]

19. Ružiak, I.; Igaz, R.; Krišt’ák, L.; Réh, R.; Mitterpach, J.; Očkajová, A.; Kučerka, M. Influence of Urea-formaldehyde Adhesive Modification with Beech Bark on Chosen Properties of Plywood. BioResources 2017, 12, 3250-3264. [CrossRef]

20. Yang, M.; Rosentrater, K.A. Life cycle assessment and techno-economic analysis of pressure sensitive bio-adhesive production. Energies 2019, 12, 4502. [CrossRef]

21. Dunky, M. Adhesives in the wood industry. In Handbook of Adhesive Technology; Pizzi, A., Mittal, K.L., Eds.; Marcel Dekker: New York, NY, USA, 2003; Chapter 47, pp. 872-941.

22. Jivkov, V.; Simeonova, R.; Marinova, A.; Gradeva, G. Study on the gluing abilities of solid surface composites with different wood based materials and foamed PVC. In Proceedings of the 24th International Scientific Conference Wood Is Good-User Oriented Material, Technology and Design, Zagreb, Croatia, 18 October 2013; pp. 49-55, ISBN 978-953-292-031-4.

23. Solt, P.; Konnerth, J.; Gindl-Altmutter, W.; Kantner, W.; Moser, J.; Mitter, R.; Van Herwijnen, H. Technological performance of formaldehyde-free adhesive alternatives for particleboard industry. Int. J. Adhes. Adhes. 2019, 94, 99-131. [CrossRef] 
24. Zhang, W.; Ma, Y.; Wang, C.; Li, S.; Zhang, M.; Chu, F. Preparation and properties of lignin-phenol-formaldehyde resins based on different biorefinery residues of agricultural biomass. Ind. Crops Prod. 2013, 43, 326-333. [CrossRef]

25. Tudor, E.M.; Barbu, M.C.; Petutschnigg, A.; Réh, R.; Krišt'ák, L'. Analysis of Larch-Bark Capacity for Formaldehyde Removal in Wood Adhesives. Int. J. Environ. Res. Public Health 2020, 17, 764. [CrossRef] [PubMed]

26. Tudor, E.M.; Dettendorfer, A.; Kain, G.; Barbu, M.C.; Réh, R.; Krišt'ák, L'. Sound-Absorption Coefficient of Bark-Based Insulation Panels. Polymers 2020, 12, 1012. [CrossRef]

27. U.S. Consumer Product Safety Commission. An Update on Formaldehyde (Publication 725); U.S. Consumer Product Safety Commission: Bethesda, MD, USA, 2013.

28. Kim, K. Environment-friendly adhesives for surface bonding of wood-based flooring using natural tannin to reduce formaldehyde and TVOC emission. Bioresour. Technol. 2009, 100, 744-748. [CrossRef]

29. International Agency for Research on Cancer. IARC Classifies Formaldehyde as Carcinogenic to Humans; IARC: Lyon, France, 2004.

30. Kelly, T.J. Determination of Formaldehyde and Toluene Diisocyanate Emissions from Indoor Residential Sources (No. 97-9); California Environmental Protection Agency: Sacramento, CA, USA, 1997.

31. Réh, R.; Igaz, R.; Krišták, L.; Ružiak, I.; Gajtanska, M.; Božíková, M.; Kučerka, M. Functionality of Beech Bark in Adhesive Mixtures Used in Plywood and Its Effect on the Stability Associated with Material Systems. Materials 2019, 12, 1298. [CrossRef]

32. Antov, P.; Savov, V.; Neykov, N. Reduction of Formaldehyde Emission from Engineered Wood Panels by Formaldehyde Scavengers-A Review. In Proceedings of the 13th International Scientific Conference WoodEMA 2020 and 31st International Scientific Conference ICWST 2020 Sustainability of Forest-based Industries in the Global Economy, Vinkovci, Croatia, 28-30 September 2020; pp. 7-11.

33. Sundin, B.; Risholm-Sundman, M.; Edenholh, K. Emission of formaldehyde and other volatile organic compounds (VOC) from sawdust and lumber, different wood-based panels and other building materials: A comparative study. In Proceedings of the 26th International Particleboard/Composite Materials Symposium, Washington State University, Pullman, DC, USA, 7-9 April 1992.

34. Roffael, E.; Johnsson, B.; Engström, B. On the measurement of formaldehyde release from low-emission wood-based panels using the perforator method. Wood Sci. Technol. 2010, 44, 369-377. [CrossRef]

35. Kovatchev, G. Influence of the belt type over vibration of the cutting mechanism in woodworking shaper. In Proceedings of the 11th International Science Conference "Chip and Chipless Woodworking Processes", Zvolen, Slovakia, 13-15 September 2018; pp. 105-110.

36. Widyorini, R.; Xu, J.; Umemura, K.; Kawai, S. Manufacture and properties of binderless particleboard from bagasse I: Effects of raw material type, storage methods, and manufacturing process. J. Wood Sci. 2005, 51, 648-654. [CrossRef]

37. Pizzi, A. Recent developments in eco-efficient bio-based adhesives for wood bonding: Opportunities and issues. J. Adhes. Sci. Technol. 2006, 20, 829-846. [CrossRef]

38. Kües, U. Wood Production, Wood Technology, and Biotechnological Impacts. Universitätsverlag Göttingen. 2007. Available online: https://univerlag.uni-goettingen.de/handle/3/isbn-978-3-940344-11-3 (accessed on 17 September 2020).

39. Papadopoulou, E. Adhesives from renewable resources for binding wood-based panels. J. Environ. Prot. Ecol. 2009, 10, 1128-1136.

40. Navarrete, P.; Mansouri, H.R.; Pizzi, A.; Tapin-Lingua, S.; Benjelloun-Mlayah, B.; Pasch, H. Wood panel adhesives from low molecular mass lignin and tannin without synthetic resins. J. Adhes. Sci. Technol. 2010, 24, 1597-1610. [CrossRef]

41. Nordström, E.; Demircan, D.; Fogelström, L.; Khabbaz, F.; Malmström, E. Green binders for wood adhesives. In Applied Adhesive Bonding in Science and Technology; Interhopen Books: London, UK, 2017; pp. 47-71. [CrossRef]

42. Hemmilä, V.; Adamopoulos, S.; Karlsson, O.; Kumar, A. Development of sustainable bio-adhesives for engineered wood panels-A review. RSC Adv. 2017, 7, 38604-38630. [CrossRef]

43. Pizzi, A.; Papadopoulos, A.; Policardi, F. Wood Composites and Their Polymer Binders. Polymers 2020, 12, 1115. [CrossRef] 
44. Antov, P.; Mantanis, G.I.; Savov, V. Development of wood composites from recycled fibres bonded with magnesium lignosulfonate. Forests 2020, 11, 613. [CrossRef]

45. Taghiyari, H.R.; Tajvidi, M.; Taghiyari, R.; Mantanis, G.I.; Esmailpour, A.; Hosseinpourpia, R. Nanotechnology for wood quality improvement and protection. In Nanomaterials for Agriculture and Forestry Applications; Husen, A., Jawaid, M., Eds.; Elsevier: Amsterdam, The Netherlands, 2020; pp. 469-489.

46. Hosseinpourpia, R.; Adamopoulos, S.; Mai, C.; Taghiyari, H.R. Properties of medium-density fiberboards bonded with dextrin-based wood adhesives. Wood Res. 2019, 64, 185-194.

47. Antov, P.; Savov, V.; Neykov, N. Sustainable Bio-based Adhesives for Eco-Friendly Wood Composites. A Review. Wood Res. 2020, 65, 51-62. [CrossRef]

48. Valyova, M.; Ivanova, Y.; Koynov, D. Investigation of free formaldehyde quantity in the production of plywood with modified ureaformaldehyde resin. Wood Des. Technol. 2017, 6, 72-77.

49. Li, R.J.; Gutierrez, J.; Chung, Y.; Frank, C.W.; Billington, S.L.; Sattely, E.S. A lignin-epoxy resin derived from biomass as an alternative to formaldehyde-based wood adhesives. Green Chem. 2018, 20, 1459-1466. [CrossRef]

50. Gadhave, R.V.; Srivastava, S.; Mahanwar, P.A.; Gadekar, P.T. Lignin: Renewable Raw Material for Adhesive. Open J. Polym. Chem. 2019, 9, 27-38. [CrossRef]

51. Pizzi, A. Wood products and green chemistry. Ann. For. Sci. 2016, 73, 185-203. [CrossRef]

52. Wang, Z.; Zhao, S.; Pang, H.; Zhang, W.; Zhang, S.; Li, J. Developing eco-friendly high-strength soy adhesives with improved ductility through multiphase core-shell hyperbranched polysiloxane. ACS Sustain. Chem. Eng. 2019, 7, 7784-7794. [CrossRef]

53. Li, Z.; Wang, J.; Li, C.; Gu, Z.; Cheng, L.; Hong, Y. Effects of montmorillonite addition on the performance of starch-based wood adhesive. Carbohydr. Polym. 2015, 115, 394-400. [CrossRef]

54. Wang, P.; Cheng, L.; Gu, Z.; Li, Z.; Hong, Y. Assessment of starch-based wood adhesive, quality by confocal Raman microscopic detection of reaction homogeneity. Carbohydr. Polym. 2015, 131, 75-79. [CrossRef]

55. Santos, J.; Antorrena, G.; Freire, M.S.; Pizzi, A.; González-Álvarez, J. Environmentally friendly wood adhesives based on chestnut (Castanea sativa) shell tannins. Eur. J. Wood Wood Prod. 2017, 75, 89-100. [CrossRef]

56. Ndiwe, B.; Pizzi, A.; Tibi, B.; Danwe, R.; Konai, N.; Amirou, S. African tree bark exudate extracts as biohardeners of fully biosourced thermoset tannin adhesives for wood panels. Ind. Crops Prod. 2019, 132, 253-268. [CrossRef]

57. Lora, J.H.; Glasser, W.G. Recent industrial applications of lignin: A sustainable alternative to nonrenewable materials. J. Polym. Environ. 2002, 10, 39-48. [CrossRef]

58. Sharma, S.; Kumar, A. (Eds.) Lignin: Biosynthesis and Transformation for Industrial Applications; Springer Series on Polymer and Composite Materials, Switzerland AG; Springer Nature: Berlin/Heidelberg, Germany, 2020.

59. Mandlekar, N.; Cayla, A.; Rault, F.; Giraud, S.; Salaün, F.; Malucelli, G.; Guan, J.-P. An overview on the use of lignin and its derivatives in fire retardant polymer systems, lignin-trends and applications, 2018, InTech. Matheus Poletto, IntechOpen. Lignin Trends Appl. 2018. [CrossRef]

60. Bajwa, D.S.; Pourhashem, G.; Ullah, A.H.; Bajwa, S.G. A concise review of current lignin production, applications, products and their environmental impact. Ind. Crop. Prod. 2019, 139, 111526. [CrossRef]

61. Pizzi, A. Bioadhesives for wood and fibres. Rev. Adhes. Adhes. 2013, 1, 88-113. [CrossRef]

62. Waldron, K. Advances in Biorefineries: Biomass and Waste Supply Chain Exploitation; Woodhead Publishing: London, UK, 2014.

63. Ferdosian, F.; Pan, Z.; Gao, G.; Zhao, B. Bio-based adhesives and evaluation for wood composites application. Polymers 2017, 9, 70. [CrossRef]

64. Yotov, N.; Valchev, I.; Petrin, S.; Savov, V. Lignosulphonate and waste technical hydrolysis lignin as adhesives for eco-friendly fibreboard. Bulg. Chem. Commun. 2017, 49, 92-97.

65. Klapiszewski, Ł.; Oliwa, R.; Oleksy, M.; Jesionowski, T. Calcium lignosulfonate as eco-friendly additive of crosslinking fibrous composites with phenol-formaldehyde resin matrix. Polymers 2018, 63, 102-108. [CrossRef]

66. Jin, Y.; Cheng, X.; Zheng, Z. Preparation and characterization of phenol-formaldehyde adhesives modified with enzymatic hydrolysis lignin. Bioresour. Technol. 2010, 101, 2046-2048. [CrossRef] 
67. Antov, P.; Savov, V.; Mantanis, G.I.; Neykov, N. Medium-density fibreboards bonded with phenol-formaldehyde resin and calcium lignosulfonate as an eco-friendly additive. Wood Mater. Sci. Eng. 2020. [CrossRef]

68. Laurichesse, S.; Avérous, L. Chemical modification of lignins: Towards biobased polymers. Prog. Polym. Sci. 2014, 39, 1266-1290. [CrossRef]

69. Hemmilä, V.; Adamopoulos, S.; Hosseinpourpia, R.; Sheikh, A.A. Ammonium lignosulfonate adhesives for particleboards with pMDI and furfuryl alcohol as cross-linkers. Polymers 2019, 11, 1633. [CrossRef]

70. Miller, J.; Faleiros, M.; Pilla, L.; Bodart, A.C. Lignin: Technology, Applications and Markets, Special Market Analysis Study; RISI, Inc., Market-Intell LCC: Charlottesville, VA, USA, 2016.

71. Berlin, A.; Balakshin, M. Industrial Lignins: Analysis, Properties, and Applications. In Bioenergy Research: Advances and Applications; Chapter 18; Gupta, V.K., Tuohy, M., Kubicek, C., Saddler, J., Xu, F., Eds.; Elsevier: Amsterdam, The Netherlands, 2014; pp. 315-336.

72. Lora, J. Industrial commercial lignins: Sources, properties and applications. In Monomers, Polymers and Composites from Renewable Resources; Belgacem, M.N., Gandini, A., Eds.; Elsevier: Amsterdam, The Netherlands, 2008; pp. 225-241.

73. EN 310. Wood-Based Panels-Determination of Modulus of Elasticity in Bending and of Bending Strength; European Committee for Standardization: Brussels, Belgium, 1999.

74. EN 317. Particleboards and Fibreboards-Determination of Swelling in Thickness after Immersion in Water; European Committee for Standardization: Brussels, Belgium, 1998.

75. EN 322. Wood-Based Panels-Determination of Moisture Content; European Committee for Standardization: Brussels, Belgium, 1998.

76. EN 323. Wood-Based Panels-Determination of Density; European Committee for Standardization: Brussels, Belgium, 2001.

77. EN ISO 12460-5. Wood-Based Panels-Determination of Formaldehyde Release-Part 5. Extraction Method (Called the Perforator Method); European Committee for Standardization: Brussels, Belgium, 2015.

78. Kyuchukov, G.; Jivkov, V. Furniture Construction. Structural Elements and Furniture Joints, 1st ed.; Bismar: Sofia, Bulgaria, 2016; 452p.

79. Jivkov, V.; Grbac, I. Influence of the cyclic loading on bending strength of different end corner joints made of MDF. In Proceedings of the 22nd International Scientific Conference "Wood is good-EU Preaccession Challenges of the Sector", Zagreb, Croatia, 21 October 2011; pp. 59-66.

80. Roffael, E. Volatile organic compounds and formaldehyde in nature, wood and wood based panels. Holz. Roh. Werkst. 2006, 64, 144-149. [CrossRef]

81. Salem, M.Z.M.; Böhm, M. Understanding of formaldehyde emissions from solid wood: An overview. BioResources 2013, 8, 4775-4790. [CrossRef]

82. Schäfer, M.; Roffael, E. On the formaldehyde release of wood. Holz. Roh. Werkst. 2000, 58, 259-264. [CrossRef]

83. Birkeland, M.J.; Lorenz, L.; Wescott, J.M.; Frihart, C.R. Determination of native (wood derived) formaldehyde by the desiccator method in particleboards generated during panel production. Holzforschung 2010, 64, 429-433. [CrossRef]

84. European Committee for Standardization, EN 312. Particleboards-Specifications; European Committee for Standardization: Brussels, Belgium, 2010.

85. European Committee for Standardization, EN 622-5. Fibreboards-Specifications-Part 5: Requirements for Dry Process Boards; European Committee for Standardization: Brussels, Belgium, 2010.

Publisher's Note: MDPI stays neutral with regard to jurisdictional claims in published maps and institutional affiliations.

(C) 2020 by the authors. Licensee MDPI, Basel, Switzerland. This article is an open access article distributed under the terms and conditions of the Creative Commons Attribution (CC BY) license (http://creativecommons.org/licenses/by/4.0/). 